\title{
Bronchogenic Intraspinal Cyst-A Rare Case of Spinal Cystic Space Occupying Lesion
}

\author{
Das $\mathrm{S}^{1}$, Islam $\mathrm{MM}^{2}$, Zahan $\mathrm{KFI}^{3}$, Rashid $\mathrm{MM}^{4}$, Ashfaq $\mathrm{M}^{5}$, Islam $\mathrm{MR}^{6}$, Khan $\mathrm{MSI}^{7}$
}

Conflict of Interest: There is no conflict of interest relevant to this paper to disclose.

Funding Agency: This was not funded by any institute or any group. Contribution of Authors :

Principal Investigator - Dr. Sukriti Das Data Collection- Dr. Md. Moidul Islam, Dr. Kanij Fatema Ishrat Zahan, Dr. Md. Mamunur Rashid.

Manuscript Preparation- Dr. Musannah Ashfaq, Dr. Mohammed, Shamsul Islam Khan.

Editorial Formatting- Dr. Md. Rakibul Islam.

Copyright: @2020bang.BJNS published by BSNS. This article is published under the creative commons CC-BY-NC license. This license permits use distribution (https://creativecommons. orgf/licences/by-nc/4-0/)reproduction in any medium, provided the original work is properly cited and is not used for commercial purposes.

Received: 2 January 2019

Accepted: 19 march 2019

\begin{abstract}
:
A 55 year old female patient presented with progressive back pain of 6 month duration, aggravated on lying down, associated with weakness and numbness of the both lower limbs for since 4 months. On neurological examination, the tone was found increased in both the lower limbs with a subjective power of grade 3/5 in both the lower limbs. Ankle and knee jerks were brisk with hypoaesthesia below D12 dermatomes bilaterally, plantars were extensor. A clinical diagnosis of involvement of D9 spinal level lesion was made. Magnetic resonance imaging (MRI) of the dorsolumbar spine showed an intradural extramedullary ventrally placed lesion at the D8D9 vertebral level with significant compression of the spinal cord [Figure 1, 2, 3]. The lesion appeared hyperintense on T2W image with no contrast enhancement and with significant compression and shifting of the cord to the left. After preoperative routine hematological investigations, she underwent operation by laminectomy of $D 8-D 9$ vertebrae and total excision of the cystic lesion was performed [Figure 4, 5]. Histological examination revealed respiratory type pseudostratified ciliated columnar cells and a pathological diagnosis of bronchogenic cyst was rendered [Figure 6]. The patient had an uneventful postoperative period with subjective improvement of her symptoms with reduced spasticity \& improvement of motor grade to 4/5 in both lower limbs.
\end{abstract}

Keyword: Bronchogenic, Intraspinal, Cystic.

Bang. J Neurosurgery 2020; 9(2): 146-150
A 55 year old female patient presented with progressive back pain of 6 month duration, aggravated on lying down, associated with weakness and numbness of the both lower limbs for 4 months. On neurological examination, the tone was found increased in both the lower limbs with a subjective power of grade $3 / 5$ in both the lower limbs. Ankle and knee jerks were brisk with hypoaesthesia below D12 dermatomes bilaterally, plantars were extensor. A clinical diagnosis of involvement of D9 spinal level lesion was made.
Magnetic resonance imaging (MRI) of the dorsolumbar spine showed an intradural extramedullary ventrally placed lesion at the D8-D9 vertebral level with significant compression of the spinal cord [Figure 1 , $2,3]$. The lesion appeared hyperintense on T2W image with no contrast enhancement and with significant compression and shifting of the cord to the left. After preoperative routine hematological investigations, she underwent operation by laminectomy of D8-D9 vertebrae and total excision of

1. Dr. Sukriti Das, Asscociate Professor, Department of Neurosurgery, Dhaka Medical College \& Hospital, Dhaka.

2. Dr. Md. Moidul Islam, Resident, Department of Neurosurgery, Dhaka Medical College \& Hospital, Dhaka.

3. Dr. Kanij Fatema Ishrat Zahan, Assistant Professor, Department of Neurosurgery, Dhaka Medical College \& Hospital, Dhaka.

4. Dr. Md. Mamunur Rashid, Phase-B, Resident, Department of Neurosurgery, Dhaka Medical College \& Hospital, Dhaka.

5. Dr. Musannah Ashfaq, Phase-B, Resident, Department of Neurosurgery, Dhaka Medical College \& Hospital, Dhaka.

6. Dr. Md. Rakibul Islam, Phase-B, Resident, Department of Neurosurgery, Dhaka Medical College \& Hospital, Dhaka.

7. Dr. Mohammed. Shamsul Islam Khan, Medical Officer, Department of Neurosurgery, Dhaka Medical College \& Hospital, Dhaka.

Address of Correspondence: Dr. Sukriti Das, Asscociate Professor, Department of Neurosurgery, Dhaka Medical College \& Hospital, Dhaka, Bangladesh. Cell Phone:+8801711676848, E-mail: sukriti66@yahoo.com 
the cystic lesion was performed [Figure 4, 5]. Histological examination revealed respiratory type pseudostratified ciliated columnar cells and a pathological diagnosis of bronchogenic cyst was

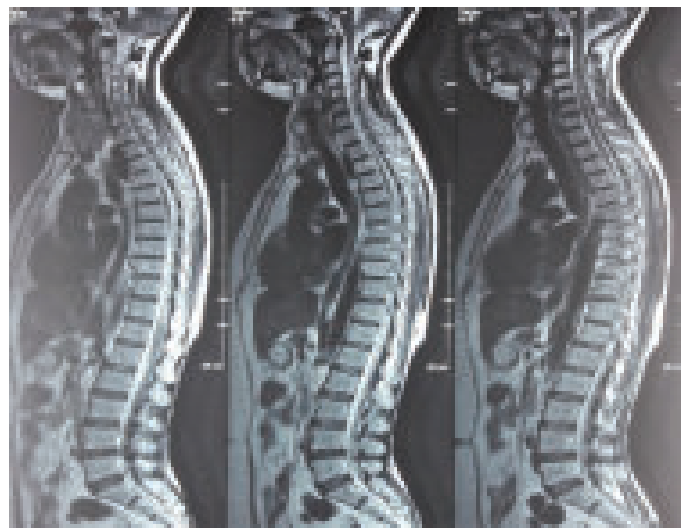

Fig.-1: Pre-operative MRI $\left(T_{2} W I\right)$-sagittal screening film

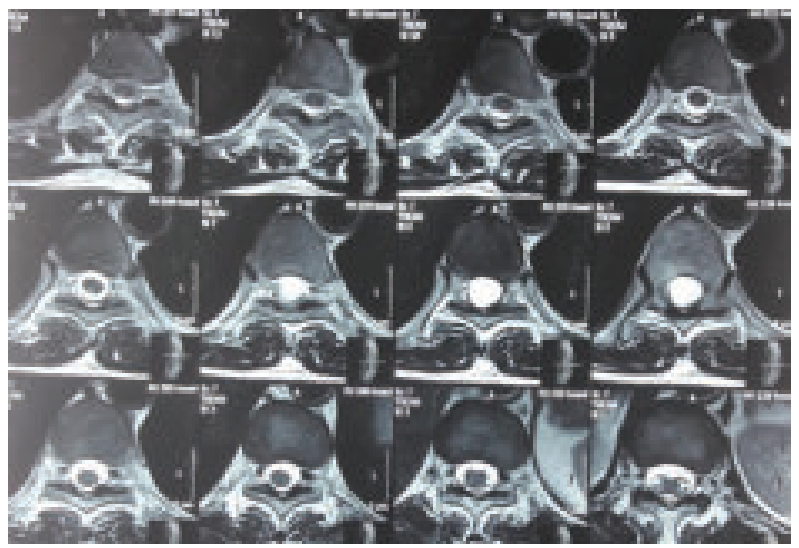

Fig.-3: Pre-operative MRI $\left(T_{2} W I\right)$ of dorsal spine-axial film rendered [Figure 6]. The patient had an uneventful postoperative period with subjective improvement of her symptoms with reduced spasticity \& improvement of motor grade to $4 / 5$ in both lower limbs.

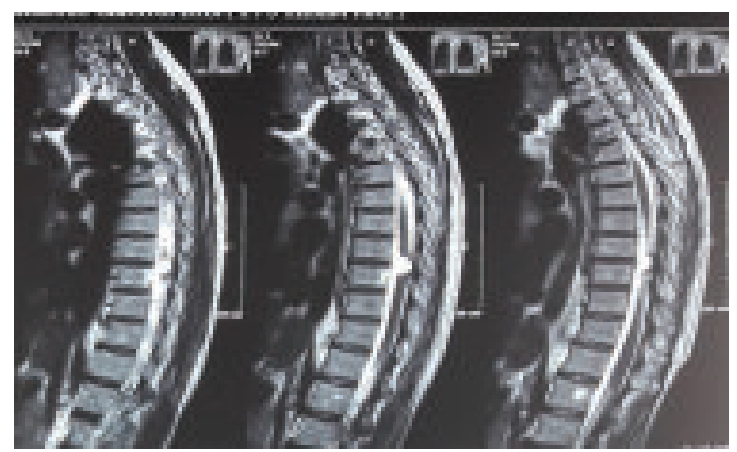

Fig.-2: Pre-operative MRI $\left(T_{2} W I\right)$ of dorsal spinesagittal film

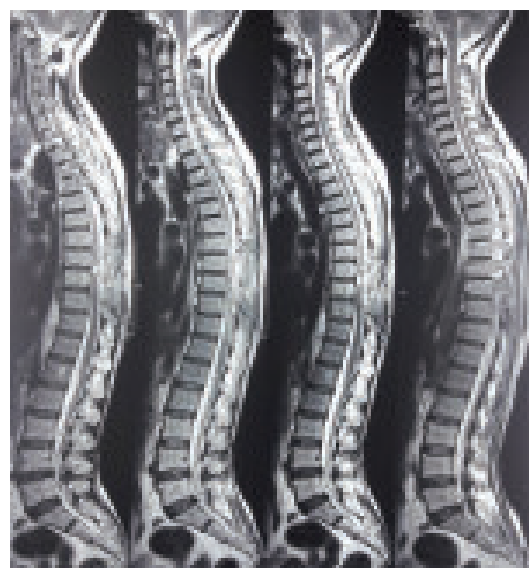

Fig.-4: Post-operative MRI $\left(T_{2}\right.$ WI)-sagittal screening film

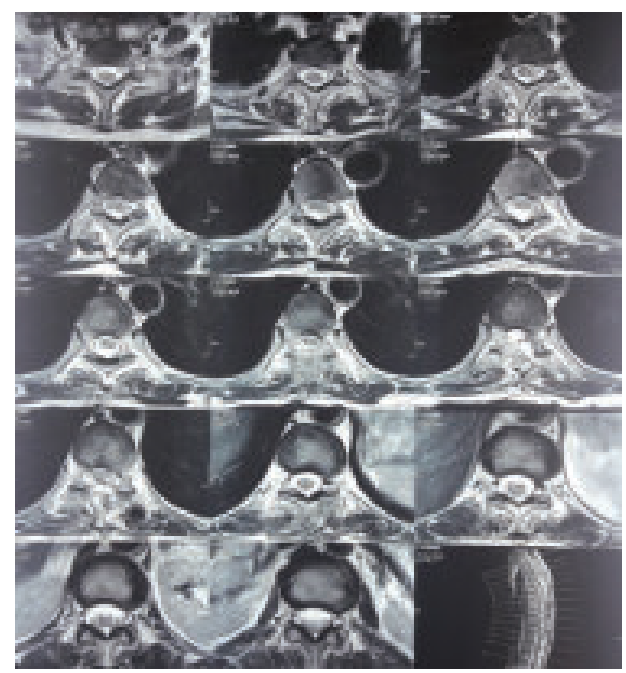

Fig.-6: Histopathology report. 


\section{Table-I}

William and Odom formulated a system to classify intrathecal cysts based upon three histopathological categories and a bronchogenic lesion is a type $A$ cyst ${ }^{4}$.

\begin{tabular}{lccc}
\hline Characteristics & Type A & Type B & Type C \\
\hline Single layer of pseudostratified columnar or cuboidal cells & + & + & + \\
mimicking respiratory or gastrointestinal epithelium & & & \\
$\begin{array}{l}\text { Complex invaginations with glandular organization; mucinous } \\
\text { or serous production; nerve ganglion, lymphoid, skeletal }\end{array}$ & - & + \\
muscle, smooth muscle, fat, cartilage and/or bone elements & & \\
Ependymal or glial tissue & - & - & + \\
\hline
\end{tabular}

Table-II

Summary of the literature review of reported cases of spinal bronchogenic cysts:

\begin{tabular}{|c|c|c|c|c|c|}
\hline Authors, Year & Symptoms & $\begin{array}{l}\text { Lesion } \\
\text { Location }\end{array}$ & Type of Lesion & $\begin{array}{l}\text { Extent of } \\
\text { Resection }\end{array}$ & $\begin{array}{c}\text { Follow-up } \\
\text { period }\end{array}$ \\
\hline Yamashita et al. ${ }^{7}$ & $\begin{array}{l}\text { Intermittent neck \& } \\
\text { left arm pain for } 4 \\
\text { years }\end{array}$ & $\mathrm{C}_{6}-7$ & $\begin{array}{l}\text { Intradural } \\
\text { extramedullary }\end{array}$ & Total & 11 months \\
\hline Ho \& Tiel $^{8}$ & $\begin{array}{l}\text { Numbness on the } \\
\text { right arm \& leg for } \\
6 \text { weeks }\end{array}$ & $\mathrm{C}_{5}-\mathrm{T}_{2}$ & $\begin{array}{l}\text { Intradural extra } \\
\text { medullary }\end{array}$ & Total & - \\
\hline Wilkinson et al. ${ }^{9}$ & $\begin{array}{l}\text { Pain, paraesthesia } \\
\text { of the right arm for } \\
2 \text { weeks }\end{array}$ & $\mathrm{C}_{3}-4$ & $\begin{array}{l}\text { Intradural extra } \\
\text { medullary }\end{array}$ & Partial & 1 year \\
\hline Baba et al. ${ }^{10}$ & $\begin{array}{l}\text { Suboccipital pain } \\
\text { for } 1 \text { year }\end{array}$ & $\mathrm{C}_{1}$ & $\begin{array}{l}\text { Intradural extra } \\
\text { medullary }\end{array}$ & Total & 1 year \\
\hline Rao et al. ${ }^{11}$ & $\begin{array}{l}\text { Pain, progressive } \\
\text { weakness of rt } \\
\text { arm for } 6 \text { wks }\end{array}$ & $\mathrm{C}_{2}-3$ & $\begin{array}{l}\text { Intraduralextram } \\
\text { edullary }\end{array}$ & Total & 3 months \\
\hline Baumann et al. ${ }^{12}$ & Acute leg pain & $\mathrm{T}_{12}-\mathrm{L}_{1}$ & $\begin{array}{l}\text { Intradural extra } \\
\text { medullary }\end{array}$ & Partial & 3 months \\
\hline Chongyi et al. ${ }^{13}$ & $\begin{array}{l}\text { Chronic lumbago } \\
\text { for } 1 \text { year, } \\
\text { progressive } \\
\text { weakness \& } \\
\text { numbness of left } \\
\text { leg for } 2 \text { weeks }\end{array}$ & $\mathrm{L}_{1}$ & $\begin{array}{l}\text { Intradural extra } \\
\text { medullary }\end{array}$ & Partial & - \\
\hline Ko et al. ${ }^{14}$ & $\begin{array}{l}\text { Skin dimple on the } \\
\text { sacrum }\end{array}$ & $\mathrm{S}_{2}$ & $\begin{array}{l}\text { Intradural extra } \\
\text { medullary }\end{array}$ & Total & 9 days \\
\hline Arnold et al. ${ }^{2}$ & $\begin{array}{l}\text { Chronic lumbago } \\
\text { for } 6 \text { months, } \\
\text { lower limb } \\
\text { weakness and } \\
\text { paraesthesia, } \\
\text { urinary } \\
\text { incontinence }\end{array}$ & $\mathrm{T}_{4}$ & $\begin{array}{l}\text { Intradural extra } \\
\text { medullary }\end{array}$ & Total & 1 year \\
\hline Yilmaz et al. ${ }^{15}$ & $\begin{array}{l}\text { Chronic lumbago } \\
\text { for } 2 \text { months and } \\
\text { paraesthesia in } \\
\text { both legs }\end{array}$ & $\mathrm{T}_{12}$ & $\begin{array}{l}\text { Intraduralextram } \\
\text { edullary }\end{array}$ & Partial & 6 months \\
\hline
\end{tabular}




\section{Discussion:}

Bronchogenic cysts are rare congenital abnormalities of the central nervous system, identified as an epithelial endodermal cyst. Neuroenteric cysts are a more common type of endodermal cyst than the bronchogenic variety accounting for $0.7-1.3 \%$ of all spinal cord tumours ${ }^{1}$. Endodermal cysts are described as a combination of gastrointestinal and/or respiratory type epithelium with the absence of other germinal layers including non-intestinal components, a vertebral anomaly, and a classical cervical or upper thoracic location 2,3 . A lesion is termed as a bronchogenic cyst if the endodermal lining is predominated with respiratory tract epithelium with pseudo stratified ciliated columnar epithelia that is normally found in the tracheo-bronchial tract. These cysts are therefore remnants of primitive foregut from which the respiratory system originates and more commonly located in the mediastinum ${ }^{2}$ (Table 1).

Mesoderm separates the first two embryonic layers endoderm \& ectoderm and grows forward from both sides of the primitive streak. Originating from the cephalic end of the primitive streak, the mesodermal notochord grows forward in the central axis. The growing notochord becomes transiently incorporated into the dorsal endoderm wall that later becomes the foregut. The endoderm extrudes it, moving dorsally between the endodermal tube and ectoderm. Somites form both sides of the notochord rod are segments of the paraxial mesoderm, with the vertebral bodies and inter vertebral discs forming from the sclerotomes fusing around the notochord. The notochord induces the surface ectoderm to form the neuro-ectoderm which forms the neural tube and subsequently the brain and spinal cord. The neural tube closes cranially too caudally, with the former opening (neuropore) closing at day 26 and later by day 27, with failure in closure resulting in anencephaly and spina bifida, respectively. Vertebral structures, meninges and skin from the remaining ectoderm develop around the closed neural tube 3,5 .

The pathogenesis and mechanism for the development of bronchogenic cysts is unknown, but three hypothesis have been proposed, including [1]; ectoendodermal adhesion which results in incomplete germ cell layer separation [2]. The cysts are of ectodermal origin, and being part of the primitive streak they are capable of differentiation to both endoderm and mesoderm ${ }^{3}$. The notochord syndrome theory more commonly seen in the lumbrosacral level, where partial duplication and separation of the notochord leads to a ventral herniation of the yolk sac or remnant gut endoderm through the notochord and subsequent fistula with the amniotic cavity. A cystic mass forms from closure of the fistula as the embryo grows from differentiated cells from the remnant of the foregut/ endodermal cell origin ${ }^{3,5}$.

The most common MR imaging findings associated with intradual extramedullary epithelial endodermal cysts are non-contrast enhancing lesions that are isointense on T1-weighted sequences and hyperintense on T2-weighted imaging. The appearance of epithelial endodermal cyst, neuroenteric or bronchogenic, on diagnostic imaging is that of a lobulated homogenous mass without an associated mural nodule ${ }^{2,6}$. Surgical resection appears to be the most effective treatment of symptomatic spinal bronchogenic cysts and recurrence is attributed to partial resection, with a rate of $11.6 \%$ reported in the literature ${ }^{2}$. It should also not be ignored that the presence of spinal development anomalies such as spina bifida may indicate further developmental spinal or vertebral malformations including spinal cysts ${ }^{3,5}$. Nine cases of spinal bronchogenic cysts reported in the English literature, all the lesions were intradural extramedullary and 5 of these arose in the cervical or upper thoracic region, 1 in the lower thoracic spine, 1 in the thoracolumbar region, 1 in the lumbar region, and 1 in the sacral region ${ }^{6}$. In our case report the patient is fifth decade of life and the clinical presentation is an indolent progressive deficit in lower limb neurology and with constipation, a reflection of the lesion compressing his cauda equina. The bronchogenic cyst is a slowly growing lesion owing to the cell micro-architecture including the tight junction between cells ${ }^{3,5}$ (Table 2).

Table 2: Summary of the literature review of reported cases of spinal bronchogenic cysts:

\section{Conclusion}

In our case, we describe an intradural, extramedullary bronchogenic cyst (Wilkins and Odoms Category B), located ventrally in the dorsal canal with no associated vertebral anomalies.

These lesions grow slowly owing to tight junctions between the epithelial cells, limiting the expansion of the cyst 11,12 . The most effective treatment of a 
symptomatic spinal bronchogenic cyst is surgical resection. However, complete resection can be challenging if the cyst is adherent to the spinal cord.

\section{References:}

1. Fortuna A, Mercuri S (1983) Intradural spinal cysts. ActaNeurochir (Wien) 68(3-4): 289-314

2. Arnold PM, Neff LL, Anderson KK, Reeves AR, Newell KL (2009) Thoracic Myelopathy Secondary to Intradural Extramedullary Bronchogenic Cyst. J Spinal Cord Med 32(5): 595-597.

3. Bentley JFR, Smith JR (1960) Developmental posterior enteric remnants and spinal malformation. The split notochord syndrome. Arch Dis Child 35(179): 76-86.

4. Wilkins RH, Odom GL (1976) Spinal intradural cysts. In: Vinken PJ, Bruyn GW (Eds). Handbook of Clinical Neurology. North Holland: Amsterdam 20: 55-102.

5. Rhaney K, Barclay GPT (1959) Enterogenous cysts and congenital diverticula of the alimentary canal with abnormalities of the vertebral column and spinal cord. J PatholBacteriol 77(2): 457-471.

6. Savage JJ, Casey JN, McNeill IT, Sherman JH (2010) Neurenteric cysts of the spine. J Craniovertebra Junction Spine 1(1): 58-63.
7. J, Maloney AF, Harris P (1973) Intradural spinal bronchogenic cyst. Case report. J Neurosurg 39(2): 240-245.

8. Ho KL, Tiel R (1989) Intraspinal bronchogenic cyst: ultrastructural study of the lining epithelium. ActaNeuropathol 78(5): 513-520.

9. Wilkinson N, Reid H, Hughes D (1992) Intradural bronchogenic cysts. J ClinPathol 45(11): 1032-1033.

10. Baba H, Okumura Y, Ando M, Imura S, Morioka K, et al. (1995) A high cervical intradural extramedullary bronchogenic cyst. Case Report Paraplegia 33: 228-232.

11. Rao GP, Bhaskar G, Reddy PK (1999) Cervical intradural extramedullary bronchogenic cyst. Neurol India 47(1): 79-81.

12. Baumann CR, Konu D, Glatzel M, Siegel AM (2005) Thoracolumbar intradural extramedullary bronchogenic cyst. ActaNeurochir (Wien) 147(3): 317-319.

13. Chongyi S, Meng Y, Dejun Y, Yingjie L, Qingpeng L (2008) Lumbar intradural extramedullary bronchogenic cyst. EurSurg Res 40(1): 26- 28.

14. Ko KS, Jeun SS, Lee YS, Park CK (2008) Sacral intraspinal bronchogenic cyst: a case report. J Korean Med Sci 23(5): 895-897

15. Yilmaz C, Gulsen S, Sonmez E, Ozger O, Unlukaplan M, et al. (2009) Intramedullary cyst of the conus medularis. J Neurosurg Spine 11(4): 477-479. 